\title{
Collecting and Compiling: The Activity of Seeking Pictures in Primary School
}

Anna Lundh and Mikael Alexandersson

\section{Abstract}

Purpose: The aim of this study is to further our understanding of the situated activity of seeking pictures. It relates to an ongoing discussion on how multimodal information literacies are enacted in different social practices.

Design/methodology/approach: In order to understand the characteristics of the communication and interactions in the activity of seeking pictures, video recordings from an ethnographic study of primary school children working with problem-centred assignments have been analysed.

Findings: The analysis reveals how the activity of seeking pictures is shaped by the assumption that pictures are different from facts and information; pictures are seen primarily as having decorative functions. The activity is also characterised by playful, yet efficient cooperation between the children; they make the activity meaningful by transforming it into a play and game activity where pictures become important as physical objects, but not as a semiotic means of learning.

Research limitations/implications: The study is limited to the activity of seeking pictures in a specific primary school; however, it shows how modes other than textual modes can be included in the study of information activities. Practical implications: The study reveals the need for developing methods for enhancing children's possibilities to critically examine and learn from visual material, such as pictures.

Originality/value: Research on information seeking and information literacies rarely focus on multimodal aspects of information activities or the seeking of pictures outside special collections, despite the increased significance of visual material in the contemporary media landscape. This paper shows how studies of multimodal information activities can be designed.

\section{Introduction}

Information activities are multimodal. When seeking, using, sharing, organising, reviewing and producing information people not only engage with tools and artefacts that include alphabetic and numerical text, but also with pictures, photographs, moving images and drawings. Furthermore, people use their bodies 
when seeking and using information (Lloyd, 2010a); they gaze, they point, they type and they talk. These types of bodily actions are also often on display in interactions with other people. However, in many models of information behaviour, information seeking and use is portrayed as solely cognitive information processing where the material aspects and consequences of information activities are overlooked (cf. Francke, 2008, p. 97).

In this article we take an interest in the activity of seeking pictures in a specific social setting. Whereas problems related to organising collections of visual material are acknowledged within the fields of Knowledge Organisation and Information Retrieval, there are still relatively few user studies specifically focussing on the seeking and use of pictures outside of special collections (Enser, 2008). The aim of this study is to enhance the understanding of the situated activity of seeking pictures in primary school, an activity that includes, for example, digital pictures available on the web.

Our study also relates to an ongoing discussion on information literacy which is characterised by the ambition to understand how different information literacies emerge in social practices, rather than to the objective of defining information literacy in generalised and standardised terms (e.g. Lloyd, 2010b; Sundin, 2008; Tuominen, Savolainen \& Talja, 2005). The setting forming the focus of this article is that of a Swedish primary school where children are engaged in a project-based method of working. This working method will be described in detail in section 3 below.

For creating an understanding of how information literacies were enacted in this setting, especially from the children's perspective, we conducted an ethnographical study where a video camera was used during the fieldwork. This presented us with the opportunity to analyse the interaction between the participants when involved in information activities, as well as to discern differences between types of interactions. Some of these differences seemed to depend on the type of tools and artefacts the children were using. It seemed as if the seeking of pictures differed from the seeking of textual information; pictures were described differently than texts and the interaction between the children when looking for pictures was of another character than when they were looking for textual artefacts. The seeking of pictures also took up a lot of the children's time during the period of study; pictures were obviously an important part of the information activities of this primary school.

Thus, in this article we will explore information seeking activities of a certain kind; activities that evolve around artefacts and tools where the main mode of representation (Francke, 2008, p. 128) is images. This will be done through an 
analysis of material that involves different modes of communication, even though we mainly focus on verbal language use.

\section{Information Literacies from a Sociocultural Perspective}

In this paper, the concept of information literacies is understood in the light of sociocultural theory as presented by neo-Vygotskian scholars such as Säljö (2000; 2005) and Wertsch (1998). This means that we connect to recent understandings of information literacies where aspects of materiality and situatedness are emphasised (e.g. Andersen, 2006; Lloyd, 2010b; Sundin, 2008; Sundin \& Francke, 2009; Tuominen, Savolainen \& Talja, 2005). In addition, we also argue that information literacies are multimodal, thus involving a whole range of modes, which include, but are not limited to, alphabetic text (cf. Jewitt, 2006; 2009).

From a sociocultural viewpoint information literacies are seen as enacted through the use of cultural tools in concrete social practices. Cultural tools (Vygotsky, 1997; Wertsch 1998, p. 17) are the physical and intellectual means which humans use for meaning making, communicating, thinking, acting and learning. It is through interaction with cultural tools humans make sense of the world. As a novice in a social practice you need to learn and understand how to use tools that are valued and sanctioned within that practice (Ivarsson, Linderoth \& Säljö, 2009). For example, as a primary school pupil, you have to appropriate or master (Wertsch, 1998, pp. 53ff) certain tools, including tools for information seeking and use. Therefore, an analysis of information activities must include the cultural tools used within this setting.

Furthermore, one of the most important cultural tools is that of spoken and written language. Language permeates and builds the foundation for information activities (Talja, Tuominen \& Savolainen, 2005, pp. 89ff; Frohmann, 2004); it is impossible to envision how questions could be formulated (Lundh, 2010; McKenzie, 2004) or how information could be produced and shared (Turner \& Allen, 2010) without the use of language.

Albeit, this emphasis on language use does not imply that other tools are unimportant in information activities (cf. Ivarsson, Linderoth \& Säljö, 2009). To become information literate in a specific social practice people need to learn how to employ and understand various tools, artefacts and modalities. This has always been the case, but perhaps even more so in contemporary society because of the implementation of information and communication tools that build on several modalities, including pictures, images and photographs (cf. Jewitt, 2009). 
Hence, to fully understand how information literacies are enacted in different settings one cannot ignore modes that are not textual (cf. Lloyd, 2007).

Moreover, the enactment of information literacies does not look the same across all types of social practices; instead information literacies must be seen as situated in specific contexts (Lloyd, 2010b; Sundin, 2008; Tuominen, Savolainen \& Talja, 2005). For this reason, it is more plausible to talk about information literacies in the plural than as one single type of literacy (Limberg, 2010). Thus, in studies of the enactment of information literacies one needs to focus on how certain tools for information activities are valued and used in the practice studied.

In our study we focus on how pictures are valued, sought and used in primary school. The analysis builds not only on the idea that information activities are multimodal, but also on the idea that the information activities studied are shaped in and by the primary school context. Primary school as an institution builds on historical traditions which include ideas of how children become literate and what it means to be literate. At the same time, situational activities taking place within primary school also contribute to the forming of this institution (cf. Linell, 2009, pp. 49ff). Thus, when we study how different modes are valued and used in the activities studied, we analyse communicative situations as they unfold, within an institutional setting.

\section{Empirical Framework}

In order to analyse information activities engendered in a primary school setting, we have chosen to study activities connected to children working with research. In this paper, the term research written in italics denotes a certain method of working in the studied setting.

The research method of school work entails an expectation that the children will independently conduct projects on topics they have chosen themselves and includes their own information seeking activities. The topics chosen by the children may be varied, for example, topics on pets and animals, nations and ethnical groups or historical epochs. Their work is conducted individually or in pairs and they are expected to produce a booklet as well as an oral presentation of their findings.

When working with their research assignments the children made use of three sites at their school: the classrooms and nearby smaller rooms where they were supported by their class teachers and sometimes a remedial teacher and an older pupil undergoing a period of practical work experience; the school library where 
they searched for books, often together with the school librarian; and, the computer room in the library where they had one lesson a week on information seeking on the Internet with an ICT-assistant. When observing the later lessons it became evident that the seeking of pictures was an important part of the children's research processes.

\subsection{Data Collection}

The empirical material of this paper was collected during a period of ethnographical fieldwork in the beginning of 2008. The participants were 31 pupils of two third-year forms (which means that most of the children were nine or ten years old), two form teachers and one IT assistant at a public coeducational school in Sweden. The research method of working had been observed in an earlier study of information seeking and ICT use in primary school (see Lundh \& Limberg, 2008) and became the main focus of the follow-up study.

The pupils' work was observed during a five week period, where two days a week were devoted to research. The data collection methods were informed by a visual ethnographical approach (Pink, 2007) and included a number of data collection methods; field notes were taken, but the major part of the observations and also informal conversations were documented with the help of a small video camera. In addition, copies were made of the booklets produced by the children. In the following analysis the video recordings are in focus.

The study followed the then-current Swedish Ethical Principles for humanistic and social scientific research, published by the Swedish Research Council (Forskningsetiska principer..., 2002), where issues of informed consent and confidentiality are stressed. In this study consent was obtained from both parents/guardians, who filled out a written form, as well as the children, who were informed about the study and gave their consent verbally. All names used in this article are aliases, and the pictures used have been edited in order to ensure the participants' confidentiality; the stylised pictures capture the participants' positions and gestures, but the faces, hairstyles and clothes have been changed significantly.

\subsection{Analysis}

After having noted that the children's seeking of pictures seemed different from other information activities the first step of the analysis was to identify episodes within this activity (cf. Linell, 1998, pp. 187f). In total we discerned 29 episodes, most of them just a few minutes long, where searching for pictures or conversations about the seeking and use of pictures were central in the interaction. The major part of the identified episodes of picture seeking took place during the lessons in the computer room, but other examples were also found. Most 
of the episodes were filmed in a way that focussed on the children rather than the staff.

The analysis was inspired by Interaction Analysis (Jordan \& Henderson, 1995), which implies detailed analyses of activities in naturalistic settings. The analytical focus lies on unfolding conversations and interactions. In the analysis we were interested in the spoken discourse that revolves around the seeking of pictures as it takes place in situ. The analysis entailed working with an everyday understanding of what constitutes a picture or an image; pictures/images are discerned as a specific mode through how they are described by the participants. Furthermore, the episodes included in the results have been represented in detailed transcripts and in two cases also been supported by pictures, in order to facilitate the understanding of the situations as they appeared in the video recordings. Even though the analysis is mainly directed towards the conversations, the pictures are meant to give sense of the setting - the "people and place" (Sligo \& Tilley, 2011) - and thereby enhance the idea that information literacies happen in and are shaped by everyday activities.

The episodes were then thematised through a process where we worked on the basis of the material as a whole: Firstly, we identified similarities and differences in the episodes and, secondly, these similarities and differences were organised in themes. Two major themes in the participants' interactions and communication in connection with pictures were identified. The first theme, pictures as nonfacts shows how the tool of pictures is described. The second theme, which builds on the first, is called seeking pictures as a collective activity. The two themes are described in the following sections.

\section{The Activity of Seeking Pictures}

In this section, characteristics of the activity of seeking pictures will be described and illustrated through detailed empirical examples. One reason for initially considering the seeking and use of pictures as different from the seeking and use of textual material was that the participants themselves made a distinction between, on the one hand, information and facts, and on the other hand, pictures and images. Thus, the seeking and use of pictures and images was described in other terms than the seeking and use of alphabetic text. Furthermore, it seemed as if the interaction between the children when looking for pictures was of another, more cooperative, character than when they were seeking textual material. Pictures were also ascribed an importance as material artefacts in other ways than texts; pictures seemed to be artefacts to gather, show and exchange. 


\subsection{Pictures as Non-Facts and Decorations}

One of the premises for the activity of seeking pictures concerned ideas for how pictures should be used in the children's research. Overall, we find few examples in the analysed episodes where pictures are described as having functions beyond decorative ones. Instead, they are described as neutral physical objects that are not supposed to communicate any specific message on the children's topics or answers to any of the children's research questions. As we will see, this idea has consequences for how pictures are sought.

Excerpt 1 (for transcript notation see Appendix 1) is an example of how the expectations concerning the use of pictures are articulated by one of the teachers in a conversation with her young students. The conversation was recorded during an assembly in one of the classrooms where the teacher showed her pupils an example of how pictures had been used in one of their booklets (a drawing of the teacher showing the page in question can be seen in Picture 1).

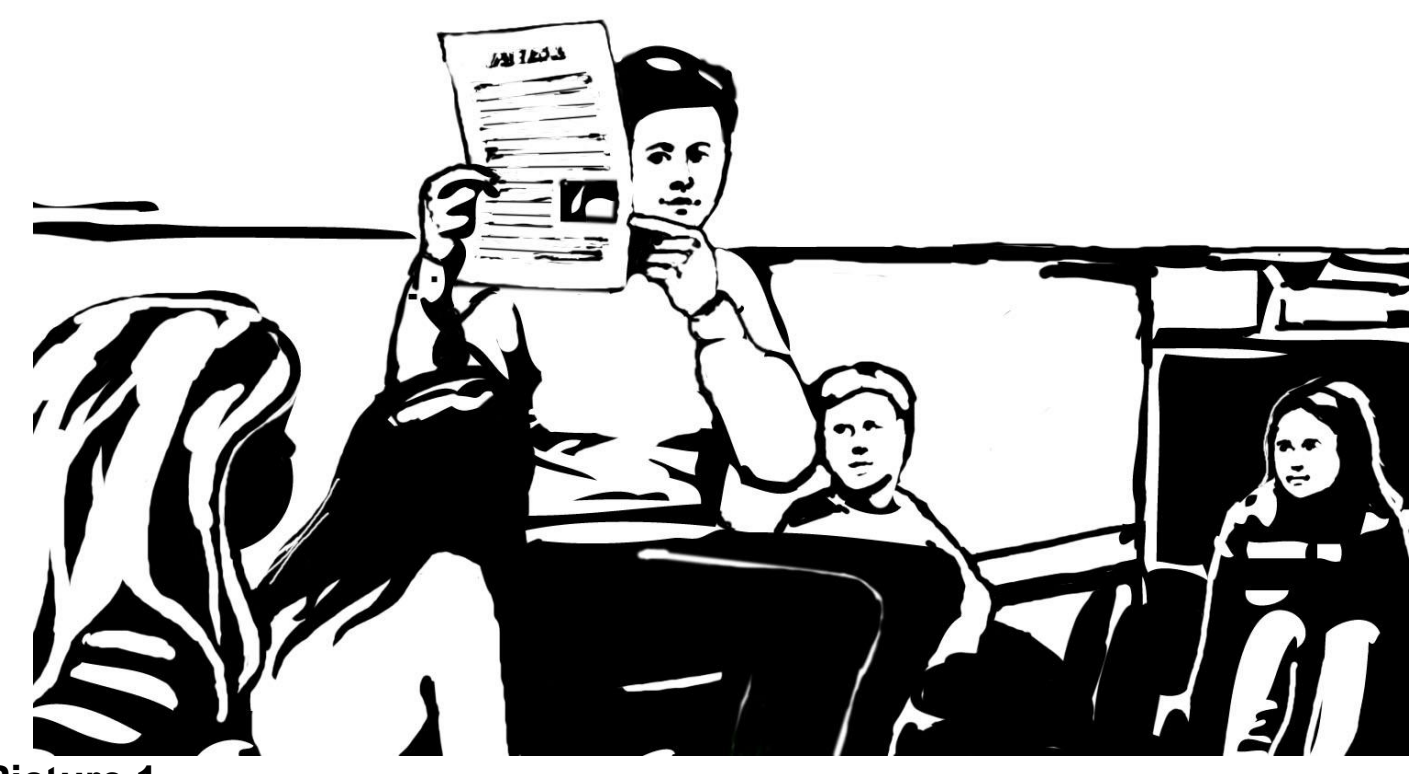

Picture 1 


\begin{tabular}{|c|c|c|}
\hline & English translation & Swedish transcript \\
\hline 1. & $\begin{array}{l}\text { Majken: }[. . .] \text { you can do it like Felicia } \\
\text { has done, you can insert }(.) \text { you know } \\
\text { on the computer it says insert picture }(.) \\
\text { you've seen that, haven't you? }\end{array}$ & $\begin{array}{l}\text { Majken: }[. . .] \text { man kan också göra så } \\
\text { här som Felicia att man infogar (.) det } \\
\text { vet ni på datorn så står det infoga bild } \\
\text { (.) det har ni sett va? }\end{array}$ \\
\hline 2. & Someone: $\mathrm{mm}$ & Någon: mm \\
\hline 3. & $\begin{array}{l}\text { Majken: insert that's when you put (it) } \\
\text { here and there (.) and then you put in a } \\
\text { small picture and in that way you'll get } \\
\text { lines next to it }(.) \text { I think this is pretty } \\
\text { smart because then it's a bit more fun } \\
\text { to read when the picture is placed like } \\
\text { this }\end{array}$ & $\begin{array}{l}\text { Majken: infoga det är ju när man sätter } \\
\text { (den) lite här och var (.) så då sätter man } \\
\text { en liten bild och då făr man ju rader här } \\
\text { bredvid (.) det tycker jag är lite smart } \\
\text { för då blir det lite roligare att läsa när } \\
\text { bilden sitter så här }\end{array}$ \\
\hline
\end{tabular}

\section{Excerpt 1}

In this sequence the picture is described by the teacher as a readymade object that can be copied and inserted into the document. Hence, the main function of the booklet seems to be to mediate written alphabetic text, rather than pictures. The document should be "fun to read" and it is important that there is room for lines to write on beside the picture. The role of pictures is described as filling space rather than as content; they are expected to be subordinated (Bezemer \& Kress, 2009) to the written text.

This solely decorative function of pictures is confirmed in the interactions and conversations in the classrooms and in the computer room. Both the staff and the children make a distinction between information or facts and pictures, where the former is represented by alphabetic text. One example of this distinction is provided in the conversation represented in Excerpt 2. Here, one of the teachers helps a pupil when he is searching on the web for information about Harley-Davidson motorbikes. In line 2 the teacher dismisses pictures, since they are not "information".

\begin{tabular}{|c|c|c|}
\hline & English translation & Swedish transcript \\
\hline 1. & $\begin{array}{l}\text { William: which page there (.) } \mathrm{mm} \text { here } \\
\text { (.) Harley [Davidson] }\end{array}$ & $\begin{array}{l}\text { William: vilken sida där (.) } \mathrm{mm} \text { här (.) } \\
\text { Harley [Davidson] }\end{array}$ \\
\hline 2. & $\begin{array}{l}\text { Pernilla: [perhaps it was] tricky to find } \\
\text { information it was only pictures }\end{array}$ & $\begin{array}{l}\text { Pernilla: [det kanske] var svårt att få in- } \\
\text { formation det var bara bilder }\end{array}$ \\
\hline 3. & $\begin{array}{l}\text { William: nope we'll have to do another } \\
\text { search } \\
\text { (another possible translation can be } \\
\text { we'll have to do a search about }(.) \text { ) }\end{array}$ & William: nä vi får söka om (.) \\
\hline
\end{tabular}

\section{Excerpt 2}


A similar division between facts and pictures is made in the dialogue in Excerpt 3 where the ICT assistant is approaching a group of boys who are working in the computer room. The ICT assistant's tone implies that the searching for facts is preferable to pictures. The response by one of the boys in line 2 , which can be seen as a defence or an explanation, reinforces the distinction between pictures and facts, where the latter can be found in books.

\begin{tabular}{|r|l|l|}
\hline & English translation & Swedish transcript \\
\hline 1. & $\begin{array}{l}\text { Anders: hey you should have some- } \\
\text { thing else not just pictures [right]? }\end{array}$ & $\begin{array}{l}\text { Anders: hörni ska väl ha lite annat än } \\
\text { bara bilder också [va]? }\end{array}$ \\
\hline 2. & $\begin{array}{l}\text { Erik: [but I have a whole book at } \\
\text { home] }\end{array}$ & Erik: [men jag har en hel bok hemma] \\
\hline 3. & $\begin{array}{l}\text { Anders: [you should search for facts as } \\
\text { well] }\end{array}$ & Anders: [ni ska söka fakta också] \\
\hline
\end{tabular}

This division between pictures as non-facts and alphabetic text as facts is also a part of the discussions among the children themselves. One illustrative example is the interaction between two girls where one of them is doing a Google search for the other in Excerpt 4. In line 1 the girl at the computer (Felicia) asks the other girl (Matilda) if she wants her to print a picture. After Matilda has chosen another picture in line 2, Felicia maintains that they also have to print ("take") the facts too. "Facts" refers to the text surrounding the pictures, which Felicia marks on the screen. In this example the connection between "facts" and written text is clear, as well as the distinction between text as facts and pictures as non-facts.

\begin{tabular}{|r|l|l|}
\hline 1. & English translation & Swedish transcript \\
\hline 2. & $\begin{array}{l}\text { Matilda: nope (I don't) (.) I want that } \\
\text { one }\end{array}$ & $\begin{array}{l}\text { Felicia: vill du ha den? } \\
\text { jag halda: nä (det vill jag inte) (.) den vill }\end{array}$ \\
\hline 3. & $\begin{array}{l}\text { Felicia: but then we'll have to take this } \\
\text { as facts and this too }\end{array}$ & $\begin{array}{l}\text { Felicia: men då får vi ta det här till } \\
\text { fakta och det med }\end{array}$ \\
\hline 4. & $\begin{array}{l}\text { Matilda: yes (.) what kind of facts is it? } \\
\text { (.) okay that's alright }\end{array}$ & $\begin{array}{l}\text { Matilda: ja (.) vad är det för fakta? }(.) \\
\text { okej det blir bra }\end{array}$ \\
\hline
\end{tabular}

\section{Excerpt 4}

In Excerpt 4 the pictures are referred to with a personal pronoun "that one". This way of labelling pictures, along with using nouns which describe what the 
pictures represent, such as "grapes", "bag of coffee", "bandy field", recurs throughout the analysed episodes. The ways in which pictures are discussed emphasises the idea of pictures as objects that can be printed and gathered - as collector's items. However, there are rarely any in-depth discussions in the material on how the pictures can be interpreted or how they could be used to respond to the children's research questions.

There are a few exceptions though, as can be seen in Excerpt 5 where a girl is sitting in the computer room looking for pictures of Sami cots as she is talking to the researcher who is behind the camera. The dialogue is driven by the researcher's question in line 2 , so in this respect it differs from most of the other episodes. Nevertheless, when the girl is discussing what the picture might depict she is referring to things she has learnt and read about the Sami people while doing her research. In this case the picture is ascribed meaning beyond being decorative; a story is being told with a basis in the picture (even if the story is not completely accurate).

\begin{tabular}{|c|c|c|}
\hline & English translation & Swedish transcript \\
\hline 1. & Johanna: I think I'll take that one & Johanna: tror jag tar den \\
\hline 2. & Researcher: and what's that? & Forskare: vad är det för nånting då? \\
\hline 3. & $\begin{array}{l}\text { Johanna: mm (.) I think it is like a }(.) \\
\text { they had their own gods you know }\end{array}$ & $\begin{array}{l}\text { Johanna: mm (.) jag tror det är nån } \\
\text { sån här (.) dom hade ju egna gudar }\end{array}$ \\
\hline 4. & Researcher: $\mathrm{mm}$ & Forskare: $\mathrm{mm}$ \\
\hline 5. & $\begin{array}{l}\text { Johanna: then I think it might be (.) } \\
\text { something similar (.) maybe something } \\
\text { like they (.) a drum or something (.) I } \\
\text { can't really tell from the picture }\end{array}$ & $\begin{array}{l}\text { Johanna: då tror jag det kan vara (.) } \\
\text { nåt liknande }(.) \text { kanske nån sån här } \\
\text { dom (.) trumma eller nåt (.) det syns } \\
\text { inte riktigt }\end{array}$ \\
\hline 6. & Researcher: no & Forskare: nä \\
\hline 7. & $\begin{array}{l}\text { Johanna: I'm not sure what it is (.) re- } \\
\text { ally ((sighs)) there is some } \\
\text { (a pause of about } 7 \text { seconds) } \\
\text { (I might) (.) ah but }(.) \text { when I have read } \\
\text { they had them to store food in }\end{array}$ & $\begin{array}{l}\text { Johanna: jag vet inte vad det är (.) rik- } \\
\text { tigt ((suckar)) där är nån } \\
\text { (ca } 7 \text { sekunders paus) } \\
\text { (jag k) (.) äsch men (.) när jag har läst } \\
\text { så hade dom det förvara mat i såna där }\end{array}$ \\
\hline 8. & Researcher: really & Forskare: jaha \\
\hline 9. & $\begin{array}{l}\text { Johanna: so the wolverines wouldn't } \\
\text { take the food }\end{array}$ & $\begin{array}{l}\text { Johanna: för att järven inte skulle } \\
\text { kunna ta maten }\end{array}$ \\
\hline 10. & Researcher: okay & Forskare: okej \\
\hline 11. & $\begin{array}{l}\text { Johanna: something like (.)wolverines } \\
\text { probably couldn't climb up there so it } \\
\text { was like a store (.) that's what I've read } \\
\text { in other books about Sami people }\end{array}$ & $\begin{array}{l}\text { Johanna: (nåt) sånt där (.) att om jär- } \\
\text { ven kunde nog inte klättra upp där så } \\
\text { var det som ett förråd (.) har jag läst i } \\
\text { andra böcker om samer }\end{array}$ \\
\hline
\end{tabular}

\section{Excerpt 5}


The girl in Excerpt 5 does not choose to print or save the picture she is talking about. Instead, another picture catches her interest and this picture is also commented on as a fun picture by the ICT assistant who passes by. After his comment, the girl hurries to print the picture.

In the first theme of the analysis, we can see that pictures, images and photographs mainly have a role as decorations in the research method of working. They are not treated as pedagogical tools from which the children can learn about their chosen topics. However, the activity of seeking pictures seems to be regarded as important by the children and is at least not seen as unnecessary by the staff. Furthermore, the communication and interaction involved in the activity of seeking pictures is lively, especially among the children. This is the second theme emerging in the analysis.

\subsection{Seeking Pictures as a Collective Activity}

The activity of seeking pictures in this setting is characterised by a high level of interaction and dialogue among the children; it can be seen as an animated and at first glance even a noisy and unstructured activity. However, a closer look makes evident that the children's seeking of pictures is undertaken systematically and efficiently.

Our analysis shows that an important part of the activity is to find the "right" kind of pictures. The children often scan a large number of pictures from the results of web searches for pictures and they make quick decisions when choosing pictures to print. An example can be seen in Excerpt 6 where one girl is starting to look for pictures for her and her writing partner's research on sports. The sequence starts with the girl typing something into the search field in Google image search. About 14 seconds later she has chosen a picture to print. While she is talking to the researcher about which printer to choose her writing partner arrives; he is a bit late for the lesson in the computer room. When he has given his excuses the girl asks him if they should print, "take out", the picture she has found and he quickly agrees; from the time he arrives it takes less than a minute for them to agree on a picture to print.

\begin{tabular}{|c|c|c|}
\hline & English translation & Swedish transcript \\
\hline 1. & $\begin{array}{l}\text { Moa: [Emil] should we take out this } \\
\text { one? }\end{array}$ & Moa: [Emil] ska vi ta ut den? \\
\hline 2. & Emil: bandy field? & Emil: bandyplan? \\
\hline 3. & Moa: $\mathrm{mm}$ & Moa: $\mathrm{mm}$ \\
\hline 4. & Emil: okay (.) I'll go and get it & Emil: okej (.) jag går och hämtar \\
\hline
\end{tabular}


In the sequence represented in Excerpt 6 the girl and the boy display confidence in knowing what they want and what they need in terms of pictures for their research. They are working under pressure; the IT lessons are only 20 minutes long and in this particular situation they have even less time since the boy was late. Through a clear division of labour and working well together their picture seeking is carried out in an efficient way. Without actually articulating any expectations Emil's role as being the one who rushes off to the printer is agreed upon. The children's evaluation of the picture also seems to be based on a tacit understanding; as a spectator one cannot tell from the children's interaction how they arrive at their decision between themselves.

Excerpt 6 reveals ways of working that seems to be common when the children work together doing web searches for pictures. A similar example, where the division of duties also seems to be clear, where decisions are made quickly and where the printing of pictures is important is provided in Excerpt 7. This excerpt, which comprises the dialogue taking place while two girls are working together at the computer, can be seen as a bit silly and giggly; the sequence starts with one of the girls formulating a query where she combines her own topic (Idre, which is a Swedish skiing resort) with the other girl's topic (rabbits). However, in line 7 one of them (Matilda) actually finds an image she wants to use. The other girl (Felicia), who is in charge of the mouse, prints the picture while being urged by Matilda to go back to the result page where they both see pictures they find suitable for Matilda. 


\begin{tabular}{|c|c|c|}
\hline & English translation & Swedish transcript \\
\hline 1. & $\begin{array}{l}\text { Matilda: that was a cat not a rabbit (.) } \\
\text { but type baby rabbits not baby rabbits } \\
\text { in Idre (.) no (type out) in Idre }\end{array}$ & $\begin{array}{l}\text { Matilda: det var (ju) en katt ingen ka- } \\
\text { nin (.) men skriv kaninungar inte ka- } \\
\text { ninungar vid Idre (.) nej (skriv bort) } \\
\text { det vid Idre }\end{array}$ \\
\hline 2. & $\begin{array}{l}\text { Felicia: ((laughs)) (.) that wasn't a } \\
\text { baby rabbit }\end{array}$ & $\begin{array}{l}\text { Felicia: ((skrattar)) (.) det var ingen } \\
\text { kaninunge }\end{array}$ \\
\hline 3. & $\begin{array}{l}\text { Matilda: it (was wait) oh please take } \\
\text { that one }\end{array}$ & $\begin{array}{l}\text { Matilda: den (var ju vänta) åh den ta } \\
\text { den }\end{array}$ \\
\hline 4. & Felicia: no take that one & Felicia: nej ta den \\
\hline 5. & Matilda: ((laughs)) & Matilda: ((skrattar)) \\
\hline 6. & Felicia: ((laughs)) & Felicia: ((skrattar)) \\
\hline 7. & $\begin{array}{l}\text { Matilda: can I see it? (.) can I see it? } \\
\text { (.) oh }\end{array}$ & $\begin{array}{l}\text { Matilda: får jag se den? (.) får jag se } \\
\text { på den? (.) åh }\end{array}$ \\
\hline 8. & Felicia: do you want that one? & Felicia: vill du ha den? \\
\hline 9. & Matilda: ohohohoh & Matilda: åhåhåhåh \\
\hline 10. & Felicia: print & Felicia: skriv ut \\
\hline 11. & $\begin{array}{l}\text { Matilda: press that one (.) quick (.) } \\
\text { and then press- }\end{array}$ & $\begin{array}{l}\text { Matilda: tryck där (.) fort (.) och så } \\
\text { tryck- }\end{array}$ \\
\hline 12. & Felicia: Matilda look here & Felicia: Matilda se här \\
\hline 13. & Matilda: I want that one & Matilda: den vill jag [ha] \\
\hline 14. & Felicia: that one is really cool & Felicia: [den] var ju cool \\
\hline 15. & Matilda: yeah but I want that one & Matilda: ja men den vill jag ha \\
\hline
\end{tabular}

\section{Excerpt 7}

In Excerpt 7 the activity of seeking pictures is characterised by playfulness; in this respect it differs from episodes when the children are looking for facts and texts. At the same time as the girls are joking and playing word games, they are nonetheless determined in their search for pictures.

The activity of seeking pictures is also characterised by cooperation and information sharing. When seeking pictures the children both show each other pictures they have found as well as carry out searches for each other. "Look at this", "look here" etc are phrases often used in the interactions, as in Excerpt 8 where five boys are sitting by three computers looking for pictures, and showing each other what they find. Picture 2, showing the five boys looking at one of the screens, is taken during the same IT lesson. 


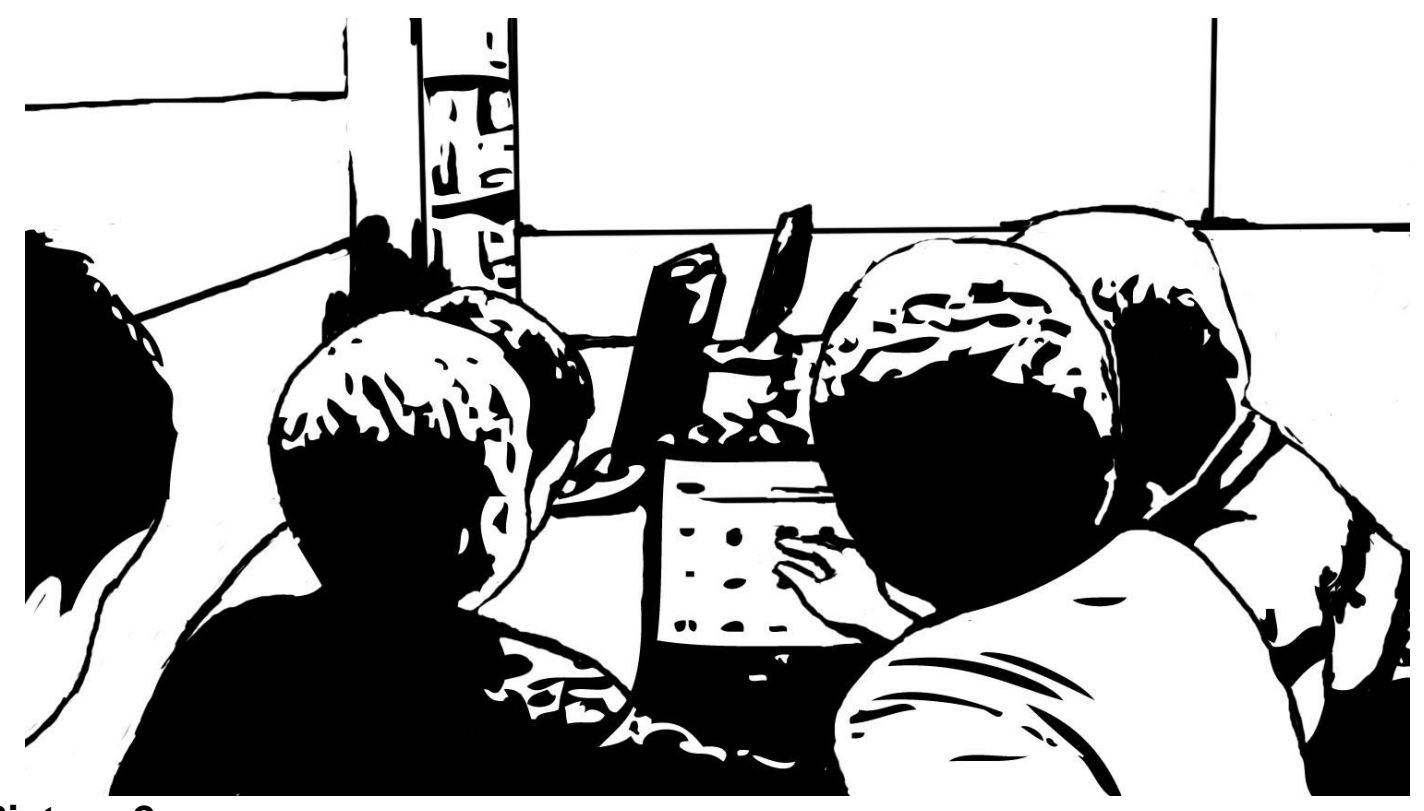

\section{Picture 2}

\begin{tabular}{|c|c|c|}
\hline & English translation & Swedish transcript \\
\hline \multirow[t]{2}{*}{1.} & $\begin{array}{l}\text { Carl: look lo- come and have a look } \\
\text { it's Baloo }\end{array}$ & $\begin{array}{l}\text { Carl: kolla kol- kom och kolla det är } \\
\text { Baloo }\end{array}$ \\
\hline & \multicolumn{2}{|c|}{$\begin{array}{c}\text { Erik gets up from his and Johan's computer to look at Carl's screen; William is approaching } \\
\text { them to. }\end{array}$} \\
\hline 2. & Carl: look there it is & Carl: kolla det är den \\
\hline 3. & William: no & William: nä \\
\hline 4. & Carl: look & Carl: kolla \\
\hline 5. & Erik: Baloo & Erik: Baloo \\
\hline \multirow[t]{2}{*}{6.} & Viktor: Erik come here & Viktor: Erik kom \\
\hline & \multicolumn{2}{|c|}{ Erik stays at Carls computer and give Carl instructions: } \\
\hline 7. & $\begin{array}{l}\text { Erik: no but I think (.) don't take that } \\
\text { one go back }\end{array}$ & $\begin{array}{l}\text { Erik: nej men jag tycker }(.) \text { ta inte den } \\
\text { gå bak }\end{array}$ \\
\hline 8. & Viktor: [Erik Erik] & Viktor: [Erik Erik] \\
\hline 9. & Carl: [the Gummi Bears] & Carl: [bumbibjörnarna] \\
\hline 10. & Viktor: come here & Viktor: kom \\
\hline 11. & Erik: yes & Erik: ja \\
\hline \multicolumn{3}{|c|}{ Erik moves from Carl's computer to Viktor's computer } \\
\hline 12. & Viktor: look ( ) a lego figure & Viktor: titta Olegogubbe \\
\hline 13. & Erik: ((laughs)) & Erik: ((skrattar)) \\
\hline 14. & Johan(?): can I see & Johan(?): jag får se \\
\hline & \multicolumn{2}{|c|}{ Johan also gets up from his computer to look at Viktor's screen } \\
\hline 15. & Erik: a zombie lego figure & Erik: zombielegogubbe \\
\hline & \multicolumn{2}{|c|}{$\begin{array}{l}\text { Johan takes a look and then goes back to have another look at Carl's screen. At the same } \\
\text { time William comes and looks at Viktor's screen. }\end{array}$} \\
\hline
\end{tabular}

\section{Excerpt 8}


In the sequence it seems as if the boys compete in claiming Erik's attention. Erik is the one giving instructions about what picture Carl should choose in line 7 and he is also the one Viktor wants to show his pictures to in lines 8-13. In this interaction it is as if showing fun pictures of toys and fictional characters to Erik carries a certain status within the group of boys. Similar interaction patterns can be found in other groups of children as well; pictures and images are used as a way of impressing children who for some reason are the centre of the others' attention.

As a final comment on interaction and communication among the participants when seeking pictures it can be noted that one of the main topics discussed in the interactions between the children and the ICT assistant is printers that are out of order. Even if digital tools often are used when pictures are sought the children spend time and effort on saving and storing the pictures one by one as paper copies. Included in the time spent is waiting time, often because of technical problems. Hence, one of the characteristics of the activity of seeking pictures is that of printing pictures together with expressions of frustration when technology is not working as it should.

\section{Discussion}

Based on our analysis, the activity of seeking pictures can be summarised as follows: It is shaped by the overall assumption that the primary function of pictures in the children's research assignments is to be decorative. The activity is characterised by a playful, yet efficient cooperation among the children when they are searching for pictures to print or copy in the computer room.

The seeking of pictures in this setting could be described as an activity which in many respects resembles a game and play activity, with its own set of rules. Even though the children discuss the pictures as representing objects and situations relevant for their research they do not seem to seek pictures solely to enhance their understanding of their topics. Rather, the primary goal of the play and game like activity seems to be collecting and compiling artefacts.

Thus, the activity of seeking pictures is temporarily separated from the research method of working. In our study, it seems as if the institutional "norm zone" of the primary school is temporarily converted to something that can be described as a "free zone" (see Lieberg, 1995) where the utilitarian dimensions of school activities are bracketed and a more play-like set of rules apply. The computer room becomes a site where the activity of seeking pictures is detached from the overall research practice; it resembles cultural patterns which usually emerge at the borders of and outside of school, in game and play activities. 
This comparison between the activity of seeking pictures and game and play activities can be done in at least three respects. Firstly, on a general level, play and game activities include imaginary situations; a child can play when he is able to "act independently of what he sees" (Vygotsky, 1978, p. 97), thus giving something a meaning beyond its immediate appearance. In our examples, the children seem to act as if they are looking for pictures for other reasons than only to include them in their school assignments.

Secondly, Vygotsky (1978) argues that all play and game activities are based on more or less formalised rules. The emphasis on the rules and principles of organisation as one of the key characteristics of game activities and which separate them from other activities is also noted in the writings of the French sociologist Roger Caillois (2001; see Linderoth, 2004, p. 25f). In his categorisations of games, Caillois makes a distinction between games based on agon, competition or struggle, and games based on alea, chance and hazard. In our analysis we can see how the activity of seeking pictures is transformed to a kind of game activity with its own set of rules based on alea. When the pupils in our study are searching for pictures there is an element of chance involved; they type in a few terms without a clear idea of what kind of results this might lead to. It seems as if this aspect of chance creates a dimension of a game, not unlike a lottery or a tombola where you might or might not win.

Thirdly, on a more specific level, an analogy can be drawn between the activity of seeking pictures and activities connected to the collection of trading cards. The collection of trading cards also involves elements of hazard created by the idea of having complete sets and not being able to know the contents of a package of cards before purchasing it (Buckingham \& Sefton-Green, 2004, p. 26; see also Nelson \& Steinberg, 1997). The activity of seeking pictures in our examples becomes a matter of collecting physical artefacts and just like trading cards, the pictures seem to be ascribed an emotional value and used for impressing one another (cf. Brougère, 2004, pp. 196f). The activity of seeking pictures seems to be taking place in an intersection between school activities and leisure time activities in the same way as trading card activities during school hours often do (Fast, 2007, p. 217; Brougère, 2004, p. 206).

The children's transformation of the activity of seeking pictures into a type of game activity could perhaps be seen as a form of resistance to school work or as a sign of laziness. However, we would argue that the collector's culture created among the children is in line with the idea of written text as the significant mode of communication when working with research and pictures as solely decorative additions. With these types of assumptions about picture use, where the 
communicative potentials of pictures are not thoroughly explored, the children's way of acting can be viewed as a constructive way of making the activity meaningful, interesting and challenging.

\section{Conclusions}

In this paper we maintain that information literacies are not merely text-based but must be regarded as multimodal literacies. This argument is supported by our empirical material; the analysed episodes show that primary school children are engaging in information activities that include the seeking, use, sharing and organising of pictures, in addition to alphabetic text. However, the requirements for the seeking and use of pictures are different from the requirements for the seeking and use of text in this context.

Our study shows that even though the seeking of pictures is an activity that is valued at this primary school, texts are seen as the prime tool for the research method of working. Within this social practice, pictures are valued as decorative artefacts, but they are not used as a communicative way of answering the children's research questions. Communication around pictures is often focussed on showing each other artefacts and deciding whether they are "winning tickets" or not. Thus, what the children do is to evaluate and assess documents on the basis of their immediate appearance, but they do not critically examine them; there seems to be room for exploring the possibilities of how pictures can be used in primary school as semiotic tools alongside other modalities.

However, the resemblance to play activities discussed in the previous section should not be regarded as a problem, but rather as having potential in an educational setting. The seeking of pictures is an activity that seems to catch the children's interest, not only in relation to their own work but also in each other's work. Furthermore, it relates to practices outside the school context and it shows how the children in this way are able to make a school activity meaningful. What we do not see in our empirical material are pedagogues who help the children to explore the semiotic potentials of pictures.

On a methodological level, we have in this paper emphasised that multimodal aspects are often overlooked in studies of information activities, even though most information activities include several modalities. Our study shows that in order to understand and question multimodal aspects of information activities, methods that make multimodal analyses possible must be employed. This study is limited to the activity of seeking pictures and the analysis is mainly directed towards spoken discourse, but it can still be seen as one example of how other modes besides textual modes can be studied to gain a deeper and richer understanding of the enactment of information literacies in various contexts. 


\section{Acknowledgements}

The writing of this paper has been conducted at The Linnaeus Centre for Research on Learning, Interaction and Mediated Communication in Contemporary Society (LinCS). The authors would like to thank the study participants who generously shared their activities with us. We would also like to thank Louise Limberg for valuable comments on this paper; Frances Hultgren and Keith Hampson for their assistance on issues concerning the English language; and Rebecca Landmér for the editing of the pictorial material.

\section{References}

Andersen, J. (2006), "The public sphere and discursive activities: information literacy as sociopolitical skills", Journal of Documentation, Vol. 62 No. 2, pp. 213228.

Antaki, C. (2002). "CA tutorial: notation. an introductory tutorial in Conversation Analysis", available at:

http://www-staff.lboro.ac.uk/ ssca1/notation.htm (accessed 5 November 2010).

Bezemer, J. \& Kress, G. (2009), "Visualizing English: a social semiotic history of a school subject", Visual Communication, Vol. 8, No. 3, pp. 247-262.

Brougère, G. (2004), "How much is a Pokémon worth?: Pokémon in France", in Tobin, J.J. (Ed.), Pikachu's Global Adventure: The Rise and Fall of Pokémon, Duke University Press, Durham, NC, pp. 187-208.

Buckingham, D. \& Sefton-Green, J. (2004), "Structure, agency, and pedagogy in children's media culture", in Tobin, J.J. (Ed.), Pikachu's Global Adventure: The Rise and Fall of Pokémon, Duke University Press, Durham, NC, pp. 12-33.

Caillois, R. (2001), Man, play and games, University of Illinois Press, Urbana, Ill.

Enser, P.G.B. (2008), "Visual image retrieval”, in Cronin, B. (Ed.), Annual review of information science and technology (ARIST) Vol 42, American Association of Information Science and Technology, New York, pp.3-42. 
Fast, C. (2007). Sju barn lär sig läsa och skriva: familjeliv och populärkultur i möte med förskola och skola. [Seven children learn to read and write: family life and popular culture in contact with preschool and primary school.] Uppsala universitet, Uppsala.

Forskningsetiska principer inom bumanistisk-sambällsvetenskaplig forskning. [Ethical principles for research in the humanities and social sciences] (2002). Stockholm: Vetenskapsrådet, available at

http://www.cm.se/webbshop_vr/pdfer/etikreglerhs.pdf (accessed 4 April 2011).

Francke, H. (2008). (Re)creations of scholarly journals: document and information architecture in open access journals. Göteborgs universitet, Göteborg.

Frohmann, B. (2004), "Documentation redux: prolegomenon to (another) philosophy of information", Library Trends, Vol. 52 No. 3, pp. 387-407.

Ivarsson, J., Linderoth, J., \& Säljö, R. (2009), 'Representations in practices: a sociocultural approach to multimodality in reasoning", in Jewitt, C. (Ed.), The Routledge Handbook of Multimodal Analysis, Routledge, London, pp. 201-212.

Jewitt, C. (Ed.) (2009), The Routledge handbook of multimodal analysis, Routledge, London.

Jewitt, C. (2006), Technology, literacy and learning: a multimodal approach. Routledge, London.

Jordan, B. \& Henderson, A. (1995). "Interaction analysis: foundations and practice", The Journal of the Learning Sciences, Vol. 4, No. 1, pp. 39-103.

Lieberg, M. (1995), "Teenagers and public space", Communication Research, Vol. 22 No. 6, pp. 720-744.

Limberg, L. (2010), "Information Literacies at the intersection between information seeking and learning: contexts and values", Introductory paper at the International Information Literacies Research Network seminar at CoLIS7, 23 June 2010, London, available at: http:/ / hdl.handle.net/2320/6536 (accessed 5 November 2010).

Linderoth, J. (2004), Datorspelandets mening: bortom idén om den interaktiva illusionen. [The meaning of gaming: beyond the idea of the interactive illusion] Göteborgs universitet, Göteborg. 
Linell, Per (2009). Rethinking language, mind, and world dialogically: interactional and contextual theories of human sense-making. Charlotte, NC: Information Age Publ.

Linell, P. (1998), Approaching dialogue: talk, interaction and contexts in dialogical perspectives, John Benjamins Publishing, Philadelphia.

Lloyd, A. (2010a), "Corporeality and practice theory: exploring emerging research agendas for information literacy", Information Research, Vol. 15 No. 3 colis794, available at: http://InformationR.net/ir/15-3/colis7/colis704.html (accessed 5 November 2010).

Lloyd, A. (2010b), "Framing information literacy as information practice: site ontology and practice theory" Journal of Documentation, Vol. 66 No. 2, pp. 245258.

Lloyd, A. (2007), "Recasting information literacy as sociocultural practice: implications for library and information science researchers", Information Research, Vol. 12 No. 4 paper colis34, available at:

http://InformationR.net/ir/12-4/colis34.html (accessed 5 November 2010).

Lundh, A. (2010), "Studying information needs as question-negotiations in an educational context: A methodological comment", Information Research, Vol. 15 No. 4 paper colis 722 , available at:

http://informationr.net/ir/15-4/colis722.html (accessed 30 March 2011).

Lundh, A. \& Limberg, L. (2008). Information practices in elementary school. Libri, Vol. 58 No. 2, pp. 92-101.

McKenzie, P.J. (2004), "Positioning theory and the negotiation of information needs in a clinical midwifery setting", Journal of the American Society for Information Science and Technology, Vol. 55 No. 8, pp. 685-694.

Nelson, M.R. \& Steinberg, S. (1997). "Dealing from the bottom of the deck: the business of trading cards, past to present", in Steinberg, S.R. \& Kincheloe, J.L. (Eds.), Kinderculture: The Corporate Construction of Childhood, Westview, Boulder, Colo., pp. 181-205.

Pink, S. (2007), Doing visual ethnography: images, media and representation in research, SAGE, London.

Sligo, F.X. \& Tilley, E. (2011). "When words fail us: using visual composites in research reporting”, Visual Communication, Vol. 10 No. 1, pp. 63-85. 
Sundin, O. (2008), "Negotiations on information-seeking expertise: a study of web-based tutorials for information literacy", Journal of Documentation, Vol. 64 No. 1, pp. 24-44.

Sundin, O. \& Francke, H. (2009), "In search of credibility: pupils' information practices in learning environments", Information Research, Vol. 14 No. 4 paper 418, available at: http://InformationR.net/ir/14-4/paper418.html (accessed 5 November 2010).

Säljö, R. (2005), Lärande och kulturella redskap: om lärprocesser och det kollektiva minnet [Learning and cultural tools: on learning processes and the collective memory] Norstedts akademiska förlag, Stockholm.

Säljö, R. (2000), Lärande i praktiken: ett sociokulturellt perspektiv [Learning in practice: a sociocultural perspective] Prisma, Stockholm.

Talja, S., Tuominen, K. \& Savolainen, R. (2005), “'Isms' in information science: constructivism, collectivism and constructionism", Journal of Documentation, Vol. 61 No. 1, pp. 79-91.

Tuominen, K., Savolainen, R. \& Talja, S. (2005), "Information literacy as a sociotechnical practice”, Library Quarterly, Vol. 75 No. 3, pp. 329-345.

Turner, D. \& Allen, W. (2010), "Investigating oral information", Information Research, Vol. 15 No. 3 colis703, available at:

http://InformationR.net/ir/15-3/colis7/colis703.html (accessed 5 November 2010).

Vygotsky, L.S. (1997), "The instrumental method in psychology", in Rieber, R. W. \& Wollock, J. (Eds.), The Collected Works of L.S. Vygotsky. Vol. 3, Problems of the Theory and History of Psychology: Including the Chapter on the Crisis in Psychology, Plenum Press, New York, pp. 85-90.

Vygotsky, L.S. (1978), "The role of play in development", in Mind in Society: The Development of Higher Psychological Processes, Harvard U.P., Cambridge, Mass., pp. 92-104.

Wertsch, J.V. (1998), Mind as Action, Oxford University Press, New York. 


\section{Appendix 1, Transcription Notation}

After Antaki (2002)

\begin{tabular}{|l|l|}
\hline$()$. & Pause \\
\hline[] & Marks overlapping talk \\
\hline() & Unclear or inaudible, sometimes with a suggestion \\
\hline$=$ & $\begin{array}{l}\text { Represents occurrences where there are no notable } \\
\text { pause between two utterances }\end{array}$ \\
\hline o o & Represents quiet speech \\
\hline Underlining & Represents loud speech \\
\hline- & Represents abrupt breaks \\
\hline$(())$ & $\begin{array}{l}\text { Describes sounds and ways of talking that are hard } \\
\text { to transcribe directly }\end{array}$ \\
\hline
\end{tabular}

